\title{
Analisis Pengukuran Kualitas Pelayanan Konsumen Dengan Metode Servqual
}

\author{
Dhiana Ekowati ${ }^{1)}$, Arsyad Fadhlur Rahman ${ }^{2)}$ \\ 1,2) STIE Nusa Megarkencana Yogyakarta \\ 1)email: dhianaekowati@gmail.com \\ 2) email: arsyadfadh93@gmail.com
}

\begin{abstract}
The hospital is a health institution that is engaged in services. The quality of a service will encourage consumers to form strong bonds with the company. If the service received exceeds consumer expectations, service quality is perceived as ideal quality. Conversely, if the service received is lower than expected, the quality of the service is perceived as poor. Thus, whether the quality of service is good or not depends on the ability of service providers to consistently meet consumer expectations. This study aims to measure the service quality of the Clinical Pathology Laboratory Installation of RSUP Sarjito Yogyakarta using the Servqual Method. The subjects of this study were consumers of the Clinical Pathology Laboratory Installation of the Sarjito Hospital Yogyakarta, while the object of this study was the quality of service for the Clinical Pathology Laboratory Installation of the Sarjito Hospital Yogyakarta. The sample of this research is 99 respondents. The data analysis of this research uses SERVQUAL analysis. The results of this study indicate that the service quality of the Clinical Pathology Laboratory Dr. Sardjito Yogyakarta provides satisfaction to consumers.
\end{abstract}

Keywoard: Quality of Service, SERVQUAL

\section{A. PENDAHULUAN}

Dalam rangka peningkatan mutu dan jangkauan pelayanan rumah sakit serta pengaturan hak dan kewajiban masyarakat dalam memperoleh pelayanan kesehatan, maka pemerintah mengatur rumah sakit dengan undang-undang untuk mempermudah akses masyarakat dalam mendapatkan pelayanan kesehatan. Berkaitan dengan hal tersebut, pemerintah mewajibkan setiap rumah sakit untuk meningkatkan mutu dan mempertahankan standar pelayanan rumah sakit serta menyelenggarakan pelayanan pengobatan dan pemulihan kesehatan sesuai dengan standar pelayanan rumah sakit.

Rumah Sakit Umum Pusat Dr. Sardjito adalah rumah sakit pusat yang memiliki instalasi laboratorium patologi klinik. Sebagai penyedia jasa tentunya seluruh karyawan berharap dapat memuaskan konsumennya (pasien). Hasil wawancara peneliti dengan beberapa keluarga pasien yang menggunakan jasa Instalasi Laboratorium Patologi Klinik RSUP Dr. Sardjito Yogyakarta menunjukkan bahwa mereka kurang puas dengan 


\section{Dhiana Ekowati, Arsyad Fadhlur Rahman}

pelayanan yang diberikan karena tidak sesuai dengan apa yang mereka harapkan. Hal tersebut disebabkan karena banyaknya antrian, proses laborat yang lama menjadikan pasien terkesan kurang puas dengan layanan instalasi laboratorium patologi klinik RSUP Dr. Sardjito. Jumlah rata-rata pengguna layanan Instalasi Laboratorium Patologi Klinik RSUP Dr. Sardjito Yogyakarta adalah sebanyak 322.092 pasien/tahun. Jika dalam 1 tahun terdapat 365 hari maka dalam sehari instalasi laboratorium patologi klinik RSUP Dr. Sardjito rata-rata melayani 822 pasien sehingga wajar jika pasien/keluarga pasien sering mengeluhkan pelayanan instalasi laboratorium patologi klinik RSUP Dr. Sardjito yang lama dan kurang bersahabat.

Sebagai perusahaan jasa, tentunya rumah sakit khususnya Instalasi Laboratorium Patologi Klinik RSUP Dr. Sardjito Yogyakarta harus mengukur kualitas layanannya sehingga mengetahui apakah layanan yang diberikan sudah sesuai dengan keinginan dan kebutuhan pelanggan. Salah satu alat untuk mengukur kualitas layanan tersebut adalah dengan SERVQUAL yaitu sebuah alat ukur yang memberikan gambaran kepuasan konsumen atas layanan yang diberikan.

Beberapa penelitian tentang SERVQUAL banyak dilakukan dan menunjukkan bahwa SERVQUAL merupakan alat ukur yang dapat digunakan untuk mengukur kualitas sebuah layanan. Beberapa penelitian tersebut adalah penelitian Loekito dan Hukama (2017), Puspitasari dan Wahyuningtyas (2020), Apriyani dan Sunarti (2017), Nurjanah (2015), Yonain dan Victor (2020). Penelitian tersebut menemukan bahwa lima dimensi daya tanggap merupakan dimensi service quality yaitu dimensi bukti fisik,, keandalan, daya tanggap, jaminan dan empati yang mampu menjelaskan kepuasan konsumen. Metode ini juga dapat memberikan gambaran nilai gap pada masig-masing indikator melalui skor servqual.

Uraian di atas sejalan dengan hasil wawancara peneliti dengan pasien/keluarga pasien yang menyatakan bahwa pelayanan yang diterima tidak sesuai dengan harapan konsumen. Namun, di sisi lain karyawan instalasi laboratorium patologi klinik RSUP Dr. Sardjito sudah berupaya memberikan pelayanan terbaik. Tujuan dari penelitian ini adalah untuk menganalisis kualitas pelayanan Instalasi Laboratorium Patologi Klinik RSUP Dr. Sardjito Yogyakarta dengan menggunakan metode SERVQUAL.

\section{B. KAJIAN LITERATUR DAN TEORI}

\section{Kualitas Pelayanan}

Kotler (2009) dalam Sangadji dan Sopiah (2013:99) merumuskan bahwa kualitas merupakan suatu kondisi dinamis yang berhubungan dengan produk, jasa, manusia, proses, dan lingkungan yang memenuhi atau melebihi harapan. Kualitas memiliki hubungan yang erat dengan kepuasan konsumen. Kualitas memberikan suatu dorongan kepada konsumen untuk menjalin ikatan yang kuat dengan perusahaan. Parasuraman (Sangadji dan Sopiah 2013: 100) mendefinisikan kualitas jasa sebagai tingkat keunggulan yang diharapkan dan pengendalian atas tingkat keunggulan tersebut 
untuk memenuhi keinginan konsumen. Lebih lanjut, Tjiptono (Sangadji dan Sopiah 2013: 100) menjelaskan, apabila jasa yang diterima atau disarankan sesuai dengan yang diharapkan, kualitas jasa dipersepsikan baik dan memuaskan.

Parasuraman (Sangadji dan Sopiah 2013:99) menyatakan bahwa salah satu gap yang menyebabkan kegagalan penyampaian jasa adalah gap antara jasa yang dirasakan dan jasa yang diharapkan, yaitu adanya perbedaan persepsi antara jasa yang dirasakan dan yang diharapkan oleh konsumen. Jika keduanya terbukti sama, perusahaan akan memperoleh citra dan dampak positif. Namun, bila yang diterima lebih rendah dari yang diharapkan, kesenjangan ini akan menimbulkan permasalahan bagi perusahaan.

Kualitas pelayanan yang diberikan perusahaan sendiri dipengaruhi oleh kualitas karyawan yang dimiliki oleh perusahaan, karena karyawan memiliki peran penting dalam pelayanan yang diberikan perusahaan hal tersebut disebabkan karyawanmelakukan komunikasi langsung dengan konsumen (Tjiptono, 2014: 23). Oleh karena itu kualitas pelayanan sendiri penting untuk diperhatikan oleh perusahaan, karena dalam pelayanan sendiri perusahaan melakukan komunikasi langsung dengan konsumennya.

Model SERVQUAL (Service Quality) adalah model kualitas jasa yang hingga kini banyak dijadikan acuan dalam riset pemasaran. Model ini dikembangkan oleh Parasuraman, Zeithamel dan Berry dalam serangkaian penelitian mereka terhadap enam sektor jasa yang dilakukan lima kali yaitu pada tahun 1985, 1988, 1990, 1993 dan 1994. Dalam model ini, ditegaskan bahwa bila kinerja pada suatu atribut (atribute performance) meningkat lebih besar daripada harapan (expectation) atas atribut yang bersangkutan, maka kepuasan (dan kualitas jasa) pun akan meningkat. Begitu pula sebaliknya. Pengukuran kualitas jasa dalam model SERVQUAL didasarkan pada skala multi-item yang dirancang untuk mengukur harapan dan persepsi pelanggan, serta gap antara keduanaya daam dimensi-dimensi utama kualitas jasa. Terdapat lima dimensi utama (sesuai urutan derajat kepentingan relatifnya) (Tjiptono, 2014).

Metode Servqual adalah metode yang sering digunakan untuk mengukur kualitas pelayanan. Pengukuran mutu untuk produk fisik tidak sama dengan industri jasa. Pengukuran kualitas jasa dalam model Servqual ini didasarkan pada skala multi item yang dirancang untuk mengukur harapan dan persepsi pelanggan serta gap diantara keduanya pada lima dimensi kualitas jasa yaitu (reliabitity, daya tanggap, jaminan, empati dan bukti fisik). Analisis diawali dengan sebuah kuisioner yang disebarkan kepada konsumen, setiap item pertanyaan memiliki dua jawaban dalam skala (Likert).

Perhitungan nilai SERVQUAL dilakukan dengan langkah-langkah sebagai berikut (Tjiptono 2014: 30):

a. Mengumpulkan penilaian responden untuk setiap atribut ke dalam 5 dimensi SERVQUAL. Pengukuran dengan metode ServQual terdiri atas dua bagian yang terdiri atas pertanyaan yang bertujuan untuk mengetahui harapan konsumen akan pelayanan yang diberikan perusahaan. Sedangkan bagian kedua terdiri atas pertanyaan yang bertujuan untuk mengukur persepsi konsumen terhadap pelayanan yang diterima oleh konsumen. 


\section{Dhiana Ekowati, Arsyad Fadhlur Rahman}

\section{b. Menghitung nilai SERVQUAL Score}

Selanjutnya penilaian kualitas jasa diukur berdasarkan perhitungan gap yang terjadi akibat perbedaan antara harapan dan persepsi kinerja kualitas jasa yang diterima oleh konsumen untuk setiap pertanyaan. Untuk nilai kualitas jasa secara keseluruhan didapat dari perhitungan nilai rata-rata dari kelima dimensi ServQual. Skor Servqual untuk tiap pasang pertanyaan bagi masing-masing pelanggan dapat dihitung berdasarkan rumus (Zeithalm, et, al.,1990) dalam (Tjiptono 2014: 35), yaitu:

\section{Skor Servqual $=$ Skor Persepsi - Skor Harapan}

Jika Kualitas $(Q) \geq 1$, maka kualitas pelayanan dikatakan baik atau dapat dikatakan jika nilai yang didapat bernilai positif maka berarti perusahaan telah berhasil melebihi harapan konsumen, untuk nilai yang negatif maka kualitas jasa harus diperbaiki.

c. Merata-rata nilai setiap atribut dalam satu dimensi masing-masing responden dan diperoleh lima nilai yang mewakili untuk tiap dimensi SERVQUAL.

d. Mengalihkan nilai rata-rata masingmasing dimensi tersebut dengan presentase pembobotan yang diperoleh dari bagian kedua. Persentase didapatkan dengan membagi nilai dengan angka 100. Dan menghasilkan skor SERVQUAL Terbobot.

e. Menjumlahkan skor SERVQUAL Terbobot setiap responden lalu merata- rata jumlah skor SERVQUAL Terbobot tersebut sehingga menghasilkan nilai gap 5.

\section{Kepuasan Konsumen}

Kepuasan konsumen adalah konsep yang paling menentukan dalam pemikiran pemasaran dan riset konsumen. Konsumen yang merasa dengan puas akan suatu produk, jasa atau merek kemungkinan besar akan terus membelinya dan memberitahukan kepada yang lain perihal pengalaman-pengalaman menyenangkan yang dirasakan dengan produk, jasa atau merek tersebut. Bila tidak puas kemungkinan besar konsumen akan berganti produk atau merek dan mengadukan keluhan kepada produsen, atau konsumen lain (Peter dan Olson, 2014: 184). Kepuasan atau ketidakpuasan adalah perasaan senang atau kecewa seseorang yang berasal dari perbandingan antara kesannya terhadap kinerja produk yang riil/aktual dengan kinerja produk yang diharapkan.

\section{Standar Pelayanan Laboratorium Kesehatan}

Dasar pelayanan laboratorium adalah Peraturan Menteri Kesehatan Republik Indonesia Nomor 411/Menkes/PER/III/2010 Tentang Laboratorium Klinik. Pasal 1 ayat (1) Permenkes ini mendefinisikan laboratorium sebagai laboratorium kesehatan yang melaksanakan pelayanan pemeriksaan spesimen klinik untuk mendapatkan informasi tentang kesehatan perorangan terutama untuk menunjang upaya diagnosis penyakit, penyembuhan penyakit, dan pemulihan kesehatan. 


\section{Kerangka Penelitian}

Rumah sakit adalah suatu institusi kesehatan yang bergerak dalam bidang jasa. Kualitas suatu jasa rumah sakit akan memberikan dorongan pasien untuk menjalin ikatan yang kuat dengan rumah sakit tersebut. Jika jasa yang diterima melampaui

Kepuasan telah menjadi konsep sentral bagi aktifitas bisnis. Kepuasan berkontribusi pada sejumlah aspek krusial, seperti terciptanya loyalitas pasien, meningkatnya reputasi perusahaan berkurangnya elastisitas harga, berkurangnya biaya transaksi masa depan, dan meningkatnya efisiensi dan produktivitas karyawan. Beberapa indikator kepuasan dapat diukur melalui niat beli ulang (repurchase inntention) dan kesediaan untuk merekomendasi (willingness to recommend). Beberapa penelitian menunjukkan bahwa kualitas pelayanan yang terdiri dari: (1) Bukti fisik, (2) Keandalan, (3) Daya tanggap, (4) Jaminan dan (5) Empati sangat berpengaruh pada kepuasan (Nurmalasari, 2013; Loekito dan Hukama, 2017; Puspitasari dan Wahyuningtyas, 2020; Apriyani dan Sunarti, 2017; Wijayanto, 2015).

\section{METODE PENELITIAN}

Subyek penelitian ini adalah konsumen Laboratorium Instalasi Klinik RSUP Dr. Sardjito. Adapun objek penelitian ini adalah kualitas pelayanan konsumen. RSUP Dr. Sardjito yang beralamat di J1. Istimewa Yogyakarta. RSUP Dr. Sardjito merupakan satusatunya RSUP di Yogyakarta dan merupakan UPT Kementerian Kesehatan RI. Sampel penelitian ini sebanyak 99 pasien. Instrumen penelitian ini adalah kuesioner. Jawaban responden yang diperoleh kemudian diukur menggunakan model SERVQUAL yang menganalisis gap antara dua faktor utama, yaitu persepsi pelanggan atas layanan yang nyata mereka terima (perceived service) dengan layanan yang sesungguhnya diharapkan (expected service). Pengukuran kualitas jasa dilakukan dengan menghitung selisih nilai yang dinyatakan oleh responden untuk setiap pasangan pernyataan.

\section{Skor SERVQUAL = Skor Harapan dan Pengalaman - Skor Kenyataan.}

Selisih antara ekspetasi dengan persepsi disebut dengan kesenjangankualitas layanan atau biasa dikenal dengan sebutan "gap". Berikut interpretasi nilai gap yang telah dijelaskan oleh Ray dan Lumanando (2020):

1. Jika gap bernilai positif (persepsi $>$ harapan), maka layanan dikatakan "berkualitas" dan memuaskan.

2. Jika gap bernilai 0 (persepsi $=$ harapan), maka layanan dikatakan berkualitas tetapi tidak memuaskan.

3. Jika gap bernilai negatif (persepsi < harapan), maka layanan dikatakan tidak berkualitas dan tidak memuaskan. 


\section{Dhiana Ekowati, Arsyad Fadhlur Rahman}

\section{HASIL DAN PEMBAHASAN}

\section{Profil Responden}

Responden penelitian ini sebagian besar berjenis kelamin laki-laki (sebanyak $56,6 \%$ ), dengan rata-rata usia 28-37 tahun yang rata-rata memiliki latar pendidikan Sarjana.

\section{Pengujian Instrumen Penelitian}

Sebelum menggunakan instrumen untuk penelitian peneliti lebih dulu melakukan uji coba instrumen penelitian dengan 30 sampel. Apabila hasil penelitian valid dan reliabel maka peneliti akan melanjutkan penyebaran kuesioner untuk keseluruhan sampel penelitian. Kuesioner diberikan secara langsung oleh peneliti kepada responden penelitian yaitu pada saat mereka mendaftar atau ketika sedang mengambil hasil laboratorium. Kuesioner berisikan indikator SERVQUAL yaitu bukti fisik, keandalan, jaminan, daya tanggap dan empati yang masing-masing indikator memiliki 4 pernyataan sehingga total keseluruhan adalah 20 pernyataan untuk variabel harapan dan 20 pernyataan untuk variabel kenyataan. Hasil uji validitas variabel harapan konsumen pada Laboratorium Patologi Klinik RSUP Dr. Sardjito Yogyakarta adalah valid. Hal tersebut ditunjukkan melalui nilai r-hitung yang nilainya lebih besar daripada r-tabel dan nilai signifikansi masing-masing berada di bawah 0,05. Dengan demikian, semua item pernyataan yang dipakai pada variabel harapan konsumen dinyatakan valid (sah). Hasil uji validitas variabel kenyataan yang dirasakan konsumen dapat diketahui bahwa nilai r-hitung lebih besar dari r-tabel dan nilai signifikansi masing-masing item memiliki nilai di bawah 0,05 sehingga kuesioner tentang kenyataan yang ditemukan di lapangan adalah valid (sah) digunakan untuk penelitian. Hasil uji reliabilitas dapat diketahui bahwa instrumen dalam penelitian ini memenuhi unsur reliabilitas karena masing-masing variabel memiliki nilai Cronbach's Alpha sebesar 0,948 dan 0,952 yang nilainya lebih besar dari 0,6 .

\section{Analisis Kualitas Pelayanan Konsumen dengan SERVQUAL}

Konsep service quality pada dasarnya memberikan persepsi secara konkrit mengenai kualitas suatu layanan. Konsep service quality ini merupakan suatu revolusi secara menyeluruh, permanen dalam mengubah cara pandang manusia dalam menjalankan atau mengupayakan usaha-usahanya yang berkaitan dengan proses dinamis, berlangsung, terus menerus di dalam memenuhi harapan, keinginan dan kebutuhan.

Keberhasilan suatu tindakan jasa ditentukan oleh kualitas karena kualitas merupakan apresiasi tertinggi dari tindakan pelayanan. Unsur-unsur service quality Lima dimensi kualitas pelayanan atau dikenal dengan istilah SERVQUAL antara lain terdiri dari faktor fisik (tangibles), keandalan (reliability), responsivitas (responsiveness), jaminan (assurance), dan empati (emphaty). 
Analisis tingkat kepuasan pelanggan dilakukan dengan cara menghitung gap kesenjangan antara nilai rata-rata persepsi dengan nilai rata-rata harapan. Setelah gap/ kesenjangan diketahui maka tahap selanjutnya adalah menyimpulkan. Menurut Mustinaroh (2010), nilai kepuasan negatif (0) menunjukkan kualitas pelayanan telah melebihi tingkat kepuasan konsumen. Bila nilai kepuasan sama dengan nol $(=0)$ menunjukkan kualitas pelayanan telah sesuai dengan harapan konsumen. Nilai Gap dapat dilihat pada tabel 1 . Tabel di bawah ini merupakan ringkasan nilai kenyataan dan harapan serta nilai gap pada setiap dimensi kualitas yang digunakan dalam penelitian.

\section{Tabel 1}

\section{Analisis SERVQUAL}

\begin{tabular}{|c|c|c|c|c|c|c|c|}
\hline \multirow{2}{*}{\multicolumn{2}{|c|}{ Item }} & \multicolumn{2}{|c|}{ Kenyataan } & \multicolumn{2}{|c|}{ Harapan } & \multirow{2}{*}{ GAP } & \multirow{2}{*}{ Ranking } \\
\hline & & Total & Rerata & Total & Rerata & & \\
\hline \multicolumn{8}{|c|}{ Tangible (bukti fisik) } \\
\hline 1 & $\begin{array}{l}\text { Laboratorium memiliki } \\
\text { peralatan yang modern }\end{array}$ & 432 & 4,36 & 432 & 4,36 & 0,00 & 3 \\
\hline 2 & $\begin{array}{l}\text { Laboratorium memiliki } \\
\text { fasilitas yang berdaya tarik } \\
\text { visual }\end{array}$ & 435 & 4,39 & 422 & 4,26 & 0,13 & 2 \\
\hline 3 & $\begin{array}{l}\text { Analis laboratorium } \\
\text { berpenampilan rapi dan } \\
\text { profesional }\end{array}$ & 432 & 4,36 & 412 & 4,16 & 0,20 & 1 \\
\hline 4 & $\begin{array}{l}\text { Gedung dan area parkir } \\
\text { laboratorium luas dan aman }\end{array}$ & 414 & 4,18 & 427 & 4,31 & 0,13 & 2 \\
\hline \multicolumn{8}{|c|}{ Reliability (kehandalan) } \\
\hline 5 & $\begin{array}{l}\text { Laboratorium menyediakan } \\
\text { daftar parameter uji mampu } \\
\text { analisis }\end{array}$ & 432 & 4,36 & 432 & 4,36 & 0,00 & 3 \\
\hline 6 & $\begin{array}{l}\text { Laboratorium menyampaikan } \\
\text { jasa tepat waktu }\end{array}$ & 410 & 4,14 & 415 & 4,19 & $-0,05$ & \\
\hline 7 & $\begin{array}{l}\text { Laboratorium menyampaikan } \\
\text { jasa secara benar sejak awal }\end{array}$ & 432 & 4,36 & 412 & 4,16 & 0,20 & 1 \\
\hline 8 & $\begin{array}{l}\text { Laboratorium menyimpan } \\
\text { catatan sesuai dengan waktu } \\
\text { yang dijanjikan }\end{array}$ & 440 & 4,44 & 435 & 4,39 & 0,05 & 2 \\
\hline \multicolumn{8}{|c|}{ Responsiveness (daya tanggap) } \\
\hline 9 & $\begin{array}{l}\text { Laboratorium } \\
\text { menginformasikan kepada } \\
\text { pelanggan saat hasil analisis } \\
\text { telah selesai }\end{array}$ & 432 & 4,36 & 432 & 4,36 & 0,00 & 2 \\
\hline
\end{tabular}




\begin{tabular}{|c|c|c|c|c|c|c|c|}
\hline \multirow{2}{*}{\multicolumn{2}{|c|}{ Item }} & \multicolumn{2}{|c|}{ Kenyataan } & \multicolumn{2}{|c|}{ Harapan } & \multirow{2}{*}{ GAP } & \multirow{2}{*}{ Ranking } \\
\hline & & Total & Rerata & Total & Rerata & & \\
\hline 10 & $\begin{array}{l}\text { Laboratorium langsung } \\
\text { melayani pelanggan secara } \\
\text { cepat saat pertama kali datang }\end{array}$ & 414 & 4,18 & 417 & 4,21 & $-0,03$ & \\
\hline 11 & $\begin{array}{l}\text { Laboratorium menyatakan } \\
\text { kesediaan untuk membantu } \\
\text { menangani masalah } \\
\text { pelanggan }\end{array}$ & 427 & 4,31 & 427 & 4,31 & 0,00 & 2 \\
\hline 12 & $\begin{array}{l}\text { Laboratorium menyatakan } \\
\text { kesiapan untuk merespon } \\
\text { permintaan pelanggan }\end{array}$ & 440 & 4,44 & 425 & 4,29 & 0,15 & 1 \\
\hline \multicolumn{8}{|c|}{ Assurance (jaminan) } \\
\hline & $\begin{array}{l}\text { Laboratorium bisa } \\
\text { menumbuhkan rasa percaya } \\
\text { para pelanggan }\end{array}$ & 419 & 4,23 & 408 & 4,12 & 0,11 & 1 \\
\hline 14 & $\begin{array}{l}\text { Laboratorium membuat } \\
\text { pelanggan merasa aman } \\
\text { sewaktu melakukan proses } \\
\text { analisis }\end{array}$ & 427 & 4,31 & 427 & 4,31 & 0,00 & 2 \\
\hline 15 & $\begin{array}{l}\text { Laboratorium secara } \\
\text { konsisten bersikap sopan }\end{array}$ & 414 & 4,18 & 427 & 4,31 & $-0,13$ & \\
\hline 16 & $\begin{array}{l}\text { Laboratorium mampu } \\
\text { menjawab pertanyaan } \\
\text { pelanggan }\end{array}$ & 426 & 4,30 & 427 & 4,31 & $-0,01$ & \\
\hline \multicolumn{8}{|c|}{ Empathy (empati) } \\
\hline & $\begin{array}{l}\text { Laboratorium memberikan } \\
\text { perhatian individual kepada } \\
\text { pelanggan }\end{array}$ & 428 & 4,32 & 412 & 4,16 & 0,16 & 1 \\
\hline & $\begin{array}{l}\text { Laboratorium sungguh- } \\
\text { sungguh mengutamakan } \\
\text { kepentingan pelanggan. }\end{array}$ & 427 & 4,31 & 432 & 4,36 & $-0,05$ & \\
\hline & $\begin{array}{l}\text { Laboratorium memahami } \\
\text { kebutuhan pelanggan }\end{array}$ & 414 & 4,18 & 417 & 4,21 & $-0,03$ & \\
\hline 20 & $\begin{array}{l}\text { Jam operasional laboratorium } \\
\text { memberi kemudahan bagi } \\
\text { pelanggan }\end{array}$ & 426 & 4,30 & 426 & 4,30 & 0,00 & 2 \\
\hline
\end{tabular}

Sumber: Data Primer diolah (2020) 
Hasil pengujian pada tabel di atas menunjukkan bahwa:

1. Bukti fisik

Bukti fisik yang disediakan oleh Laboratorium Patologi Klinik RSUP Dr. Sardjito Yogyakarta mampu memberikan kepuasan kepada konsumen. Hal tersebut ditunjukkan melalui nilai gap yang masing-masing nilainya antara $0,00-0,020$, hasil ini menunjukkan angka positif. Artinya, konsumen merasa puas dengan peralatan modern, fasilitas dan daya tarik visual, analis laboratorium berpenampilan rapi dan profesional didukung gedung yang luas dan aman yang dimiliki oleh Laboratorium Patologi Klinik RSUP Dr. Sardjito Yogyakarta.

2. Kehandalan

Kehandalan yang diberikan Laboratorium Patologi Klinik RSUP Dr. Sardjito Yogyakarta berkaitan dengan daftar parameter uji mampu analisis yang memiliki nilai 0,00 (harapan sesuai dengan kenyataan). Namun pada aspek ketepatan penyampaian jasa memiliki nilai gap - 0,05 yang menunjukkan buruknya kualitas pelayanan. Hal ini disebabkan antrian panjang, sementara SDM dan waktu pelayanan terbatas.

3. Daya tanggap

Konsumen Laboratorium Patologi Klinik RSUP Dr. Sardjito Yogyakarta juga merasakan kepuasan pada daya tanggap yang diberikan oleh petugas. Hal tersebut ditunjukkan melalui nilai gap yang memiliki nilai 0 hingga 0,15 . Konsumen Laboratorium Patologi Klinik RSUP Dr. Sardjito Yogyakarta puas bahkan sangat puas terhadap ketanggapan petugas saat memberikan informasi tentang selesainya hasil analisis, kesediaan membantu menangani permasalahan pelanggan dan kesiapan dalam merespon permintaan pelanggan. Namun demikian, terdapat aspek yang memiliki nilai negatif atau konsumen menganggap buruknya kualitas pelayanan yang diberikan oleh laboratorium yaitu pada aspek kecepatan pelayanan saat pertama kali datang. Aspek ini memiliki nilai sebesar -0,03 yang menunjukkan buruknya kualitas pelayanan atau ketidakpuasan. Kecepatan memiliki nilai yang rendah mengingat RSUP Sardjito merupakan rumah sakit pusat yang harus menangani pasien dalam jumlah yang tidak sedikit.

\section{Jaminan}

Konsumen Laboratorium Patologi Klinik RSUP Dr. Sardjito Yogyakarta juga merasakan kepuasan pada aspek jaminan yang diberikan oleh petugas. Hal tersebut ditunjukkan melalui nilai gap yang memiliki nilai 0 hingga 0,11 . Hasil ini menunjukkan konsumen Laboratorium Patologi Klinik RSUP Dr. Sardjito Yogyakarta puas bahkan sangat puas terhadap jaminan yang diberikan oleh petugas karena dapat menumbuhkan rasa percaya dan konsumen merasa aman sewaktu ketika proses analisis dilakukan. Namun demikian, terdapat aspek yang memiliki nilai negatif atau konsumen menganggap buruknya kualitas pelayanan atau rendahnya tingkat kepuasan konsumen atas kinerja petugas laboratorium yaitu pada aspek konsistensi kesopanan $(-0,13)$ dan kemampuan menjawab 


\section{Dhiana Ekowati, Arsyad Fadhlur Rahman}

pertanyaan konsumen $(-0,01)$. Petugas Laboratorium Patologi Klinik RSUP Dr. Sardjito Yogyakarta dianggap kurang sopan atau bahkan kurang mampu menjawab pertanyaan konsumen dengan baik bisa jadi disebabkan oleh stress kerja karena pekerjaan yang menumpuk dan harus diselesaikan dengan cepat karena hasil laborat digunakan dokter sebagai bahan diagnosa.

5. Empati

Empati yang diberikan petugas Laboratorium Patologi Klinik RSUP Dr. Sardjito Yogyakarta. mampu memberikan kepuasan yang melebihi ekspektasi konsumen. Hal tersebut disebabkan petugas mampu memberikan perhatian individual kepada pelanggan (besarnya gap 0,16 ) dan jam operasional laboratorium yang memberikan kemudahan bagi pelanggan (besarnya gap 0,00). Namun demikian, masih ada aspek yang dianggap memiliki kualitas yang buruk sehingga mengurangi tingkat kepuasan konsumen. Aspek tersebut adalah aspek kesungguhan dalam mengutamakan kepentingan pelanggan dan kemampuan petugas dalam memahami kebutuhan pelanggan (besarnya gap $-0,05$ ). Buruknya kualitas pelayanan kedua aspek tersebut bisa jadi disebabkan karena tingkat stress yang tinggi akibat menumpuknya pekerjaan dan kurangnya sumber daya manusia pada Laboratorium Patologi Klinik RSUP Dr. Sardjito Yogyakarta (besarnya gap $0,03)$.

Secara garis besar, rata rata tingkat kepuasan pelanggan Laboratorium Patologi Klinik RSUP Dr. Sardjito Yogyakarta terdapat pada Tabel di bawah ini.

Tabel 2

Tingkat Kepuasan Pelanggan

\begin{tabular}{lccccc}
\hline \multicolumn{1}{c}{ Dimensi Kualitas } & $\begin{array}{c}\text { Rata-Rata } \\
\text { Kenyataan }\end{array}$ & $\begin{array}{c}\text { Rata-rata } \\
\text { Harapan }\end{array}$ & $\begin{array}{c}\text { Faktor } \\
\text { Pembobot } \\
(\%)\end{array}$ & $\begin{array}{c}\text { Skor } \\
\text { Kepuasan }\end{array}$ & Ranking \\
\hline $\begin{array}{l}\text { Tangible (bukti fisik) } \\
\begin{array}{l}\text { Reliability } \\
\text { (kehandalan) }\end{array}\end{array}$ & 4,33 & 4,28 & 20,00 & 4,33 & 1 \\
$\begin{array}{l}\text { Responsiveness (daya } \\
\text { tanggap) }\end{array}$ & 4,33 & 4,28 & 20,01 & 4,33 & 1 \\
$\begin{array}{l}\text { Assurance (jaminan) } \\
\text { Empathy (empati) }\end{array}$ & 4,33 & 4,30 & 20,10 & 4,33 & 1 \\
\hline Total & 4,28 & 4,27 & 19,96 & 4,26 & 3 \\
\hline
\end{tabular}

Sumber: Data Primer diolah (2020)

Tabel di atas menunjukkan bahwa rata-rata skor kepuasan untuk variabel bukti fisik, kehandalan dan daya tanggap adalah sebesar 4,33 sedangkan pada variabel jaminan dan empati masing masing memiliki nilai 4,1 dan 4,28 . Artinya, konsumen sangat puas 
dengan kualitas pelayanan yang diberikan oleh Laboratorium Patologi Klinik RSUP Dr. Sardjito Yogyakarta.

\section{PEMBAHASAN}

Rumah sakit adalah sebuah institusi pelayanan kesehatan yang menyelenggarakan pelayanan kesehatan perorangan secara paripurna yang menyediakan pelayanan rawat inap, rawat jalan, dan gawat darurat bagi masyarakat sehingga harus mampu meningkatkan pelayanan yang lebih bermutu dan terjangkau oleh masyarakat agar terwujud derajat kesehatan yang setinggi-tingginya. Hal tersebut secara tegas dijelaskan dalam Undang-Undang Republik Indonesia Nomor 44 Tahun 2009 tentang rumah sakit. Dengan demikian, sebagai penyedia jasa, pihak rumah sakit harus berupaya meningkatkan kualitas pelayanan sehingga kepuasan konsumen terjamin. Hal ini sejalan dengan instruksi pemerintah untuk mempertahankan standar pelayanan rumah sakit serta menyelenggarakan pelayanan pengobatan dan pemulihan kesehatan sesuai dengan standar pelayanan rumah sakit.

Penelitian ini dilakukan pada Instalasi Laboratorium Klinik (ILK) RSUP Dr. Sardjito yang bertugas memberikan pelayanan prima yang fokus pada keselamatan pasien sehingga pasien merasa puas. Hal ini sejalan dengan visi Instalasi Klinik RSUP Dr. Sardjito yang berupaya menjadi salah satu Laboratorium Klinik Unggulan dalam Pelayanan, Pendidikan dan Penelitian Bidang Kesehatan. Hasil observasi peneliti menunjukkan bahwa sebagian besar responden penelitian ini berjenis kelamin laki-laki dengan rata-rata usia 28-37 tahun dengan latar belakang pendidikan Sarjana.

Berdasarkan konsep SERVQUAL, hasil penelitian ini menunjukkan bahwa masih ada gap yang memiliki nilai kurang dari nol $(<0)$ yang menunjukkan adanya kesenjangan atau konsumen masih merasa belum puas terhadap pelayanan yang diberikan oleh Laboratorium Patologi Klinik RSUP Dr. Sardjito Yogyakarta terutama pada aspek fisik (gedung dan area parkir kurang luas dan aman), aspek kehandalan yang berkaitan dengan ketepatan waktu, aspek jaminan berkaitan dengan konsistensi, kesopamam dan kemampuan menjawab pertanyaan sedangkan pada aspek empati kesungguhan dan pemahaman terhadap kebutuhan pelanggan masih kurang. Hal tersebut disebabkan karena RSUP Dr. Sardjito merupakan rumah sakit pusat yang tentunya memiliki banyak pasien sedangkan SDM memiliki jumlah yang terbatas. Secara keseluruhan, skor kepuasan masing-masing dimensi memiliki angka yang lebih dari 4 sehingga dapat dikatakan bahwa secara keseluruhan, pasien atau pelanggan Laboratorium Patologi Klinik RSUP Dr. Sardjito Yogyakarta puas terhadap pelayanan yang diberikan.

Hasil penelitian ini mendukung penelitian Nurjanah (2011), Loekito dan Hutama (2017), Puspitasari dan Wahyuningtyas (2020), Dwi Aliyyah Apriyani dan Sunarti (2017) dan Yonain dan Viktor (2020) yang menyatakan bahwa kualitas pelayanan berpengaruh pada kepuasan konsumen. Beberapa penelitian menunjukkan bahwa kualitas pelayanan yang terdiri dari: (1) Bukti fisik, (2) Keandalan, (3) Daya tanggap, (4) Jaminan dan (5) Empati sangat berpengaruh pada kepuasan (Rischa Merlinda Nurmalasari, 2013; Annisa 


\section{Dhiana Ekowati, Arsyad Fadhlur Rahman}

Rahadiyarsi Loekito dan La Diadhan Hukama, 2017; Puspitasari dan Wahyuningtyas, 2020; Dwi Aliyyah Apriyani dan Sunarti, 2017; Kusuma Wijayanto, 2015).

\section{E. KESIMPULAN}

Berdasarkan penelitian yang dilakukan dapat disimpulkan bahwa:

1. Nilai gap bukti fisik 0,00_0,020 menunjukkan angka positif, artinya bukti fisik mampu memberikan kepuasan kepada konsumen.

2. Nilai gap kehandalan 0,00 artinya harapan sesuai dengan kenyataan. Namun pada aspek ketepatan penyampaian jasa memiliki nilai gap -0,05 karena adanya antrian panjang, sementara SDM dan waktu pelayanan terbatas.

3. Nilai gap daya tanggap adalah 0 hingga 0,15 artinya pada aspek ini konsumen merasa puas. Namun demikian, pada aspek kecepatan pelayanan memiliki nilai sebesar -0,03 (memiliki nilai yang rendah) karena RSUP Sardjito merupakan rumah sakit pusat yang harus menangani pasien dalam jumlah yang tidak sedikit.

4. Nilai gap jaminan terletak pada range 0 hingga 0,11 artinya konsumen sangat puas terhadap jaminan yang diberikan. Namun demikian, pada aspek konsistensi kesopanan $(-0,13)$ dan kemampuan menjawab pertanyaan konsumen $(-0,01)$ yang bisa jadi disebabkan oleh stress kerja.

5. Nilai gap empati 0,00-0,16 artinya petugas mampu memberikan kepuasan yang melebihi ekspektasi konsumen. Namun demikian, pada aspek kesungguhan besarnya gap -0,05 karena tingkat stress yang tinggi akibat menumpuknya pekerjaan dan kurangnya sumber daya manusia.

\section{DAFTAR PUSTAKA}

Apriyani, D.A. dan Sunarti (2020). Pengaruh Kualitas Pelayanan Terhadap Kepuasan Konsumen (Studi Kasus Pada Konsumen The Little A Coffee Shop Sidoarjo). Jurnal Administrasi Bisnis Universitas Brawijaya. Volume 52(2).

Loekito, A.R. dan Hukama, L.D (2017). Pengaruh Kualitas Pelayanan Terhadap Kepuasan Konsumen Laboratorium Klinik (Studi Kasus Laboratorium Klinik X Jakarta). International Journal of Social Science and Business. Vol.1 (4):265270 .

Cristina, Y. (2010). Perbandingan Harapan Dan Kenyataan Terhadap Kualitas Pelayanan Untuk Menggambarkan Kepuasan Konsumen Dengan Resep Obat Di Apotek Kimia Farma Area Manajer Bisnis Yogyakarta Periode Desember 2009 Januari 2010. Skripsi Dipublikasikan. Program Studi Farmasi. Fakultas Farmasi Universitas Sanata Dharma Yogyakarta.

Febriyanto. (2011). Analisis GAP Harapan dan Kinerja Berdasarkan Persepsi Pengunjung Taman Nasional Way Kambas di Lampung Timur. Jurnal Manajemen dan Bisnis, Vol. 2(1): 53-68. 
Ghozali. (2014). Aplikasi analisis Multivariate dengan Program SPSS. Badan Penerbit. UNDIP Semarang.

Nurjanah. (2015). Pengukuran Kualitas Pelayanan Laboratorium Dengan Menggunakan Metode Servqual (Studi Kasus: Laboratorium Teknik Industri Dasar, Universitas Gunadarma). UG Jurnal, Vol. 9 (9): 10-13.

Peter, J. Paul dan Olson, Jerry C. (2014). Perilaku Konsumen dan Strategi Pemasaran. Jakarta: Salemba Empat.

Peraturan pemerintah Republik Indonesia Nomor 65 tahun 2005 tentang Pedoman Penyusunan dan Penerapan Standar Pelayanan Minimal.

Peraturan Menteri Kesehatan Republik Indonesia No. 411/Menkes/PER/111/2010 Tentang Laboratorium Klinik.

Ray dan Lukmanando. (2020). Upaya Peningkatan Kualitas Layanan Menggunakan Metode Servqual Dan TRIZ (Studi Kasus: Cafe Giri Hills Di Kota Gresik). Seminar Nasional Sains dan Teknologi Terapan VIII 2020. Institut Teknologi Adhi Tama Surabaya.

Sangadji, E.M. dan Sopiah, (2013). Perilaku Konsumen: Pendekatan Praktis Disertai Himpunan Jurnal Penelitian . Yogyakarta: Andi.

Sugiyono. (2016). Metode Penelitian Kuantitatif, Kualitatif dan $R$ dan D. Bandung: Alfabeta.

Tjiptono, Fandy. (2014). Pemasaran Jasa. Yogyakarta: Andi.

Undang-Undang Republik Indonesia Nomor 44 Tahun 2009 tentang rumah sakit.

Puspitasari dan Wahyuningtyas. (2020). Pengaruh Kualitas Pelayanan Terhadap Kepuasan Konsumen Warung Usaha Sate Pak Pong. Jurnal Fokus, Vol. 8(8): 207-221.

Yonain dan Victor, R. (2020). Tingkat Kepuasan Mahasiswa Terhadap Kualitas Pelayanan Dengan Metode Servqual. Jurnal Magenta, Vol. 2(3): 22-23. 
